\title{
Processing of ${ }^{13} \mathrm{C}$-labelled diatoms by a bathyal community at sub-zero temperatures
}

\author{
E. Gontikaki ${ }^{1, *}$, D. J. Mayor ${ }^{1}$, B. Thornton ${ }^{2}$, K. Black ${ }^{3}$, U. Witte ${ }^{1}$ \\ ${ }^{1}$ Oceanlab, Institute of Biological and Environmental Sciences, University of Aberdeen, Aberdeen AB41 6AA, UK \\ ${ }^{2}$ Macaulay Land Use Research Institute, Craigiebuckler, Aberdeen AB15 8QH, UK \\ ${ }^{3}$ Scottish Association for Marine Science, Scottish Marine Institute, Oban PA37 1QA, UK
}

\begin{abstract}
The carbon (C) budget in bathyal permanently cold sediments was assessed by means of a pulse-chase experiment in the deep Faroe-Shetland Channel (FSC). The food pulse was simulated by adding $500 \mathrm{mg} \mathrm{C} \mathrm{m}^{-2}$ of the ${ }^{13} \mathrm{C}$-labelled marine diatom Chaetoceros radicans to sediment cores retrieved from $1080 \mathrm{~m}$ in the FSC. The fate of the tracer was followed over $6 \mathrm{~d}$ into the dissolved inorganic $\mathrm{C}$ pool $\left(\mathrm{DI}^{13} \mathrm{C}\right.$ ) as well as the bacterial and faunal (metazoan macrofauna and meiofaunalsized nematode) biomass. After $3 \mathrm{~d}$ of incubation, 14.9 and $0.81 \mathrm{mg} \mathrm{C} \mathrm{m}^{-2}$ of the algal $\mathrm{C}$ was recovered from bacterial and faunal biomass, respectively, while only $3.8 \mathrm{mg} \mathrm{C} \mathrm{m}^{-2}$ was respired. Respiration was the dominant tracer pathway after $6 \mathrm{~d}$ of incubation $\left(44 \mathrm{mg} \mathrm{C} \mathrm{m}^{-2}\right)$. Bacterial tracer uptake did not increase significantly between Days 3 and 6 . The tracer recovered from metazoan fauna at the end of the experiment constituted $3.2 \%\left(2 \mathrm{mg} \mathrm{C} \mathrm{m}^{-2}\right)$ of the total processed C, with meiofauna contributing only $\sim 1 \%$ to the total metazoan uptake. The bacterial response was characterised by varying bacterial growth efficiency (BGE). During the first half of the experiment, low respiration and high bacterial uptake of the ${ }^{13} \mathrm{C}$-labelled substrate resulted in particularly high BGE, while the opposite was observed in the second half of the incubation. We postulate that the high BGE at the start of the experiment represents the absorption and metabolism of the readily available labile components of the added organic matter $(\mathrm{OM})$. The decrease in BGE possibly corresponds to the initiation of the energetically costly hydrolytic processes necessary for the consumption of more recalcitrant OM.
\end{abstract}

KEY WORDS: Stable isotope labelling $\cdot$ Benthos $\cdot$ Bacterial growth efficiency $\cdot$ Bathyal sediments Faroe-Shetland Channel $\cdot \delta^{13} \mathrm{C} \cdot \mathrm{PLFA}$

\section{INTRODUCTION}

Production in the deep-sea is almost entirely fuelled by the import of particulate organic matter (OM) from the upper mixed layer (Gage \& Tyler 1991). Seasonal and interannual variations in the vertical particle flux to the deep sea are linked to variability in surface ocean productivity and pelagic community structure in overlying waters (Turley et al. 1995, Jickells et al. 1996, Wassmann 1998, De La Rocha \& Passow 2007). In the temperate and boreal regions of the world's oceans, a large fraction of the vertical flux arrives on the deepsea floor in episodic pulses related to phytoplankton blooms in surface waters (Billett et al. 1983, Lampitt
1985, Smith et al. 1994). Benthic processes are closely linked to the sedimentation of particulate organic carbon (POC), such that interannual variability in surface water production is 'mirrored' in deep-sea processes (Pfannkuche et al. 1999). The benthic response to these seasonal phenomena is an active field of research due to its importance for understanding ecosystem functioning in the deep ocean, as well as the biogeochemical cycling of organic carbon (OC) in deep-sea sediments (Gooday 2002).

Bacteria are considered to be the most important biological component involved in the transformation and mineralization of OC in the biosphere (Falkowski et al. 2008). They contribute to the cycles of carbon (C) and 
nutrients in 2 ways: by producing new biomass (bacterial secondary production, $\mathrm{BP}$ ) and by remineralizing OC and nutrients (bacterial respiration, BR) (del Giorgio \& Cole 1998). The relative magnitudes of $B R$ and $\mathrm{BP}$ are expressed by the bacterial growth efficiency (BGE), which represents the amount of new bacterial biomass produced per unit of substrate assimilated and hence the efficiency with which $\mathrm{C}$ is made available to higher trophic levels (del Giorgio \& Cole 1998). The factors that influence BGE are currently not well understood, and as a result the real magnitude of OC flow through bacteria in the world's oceans remains largely unknown (del Giorgio \& Cole 2000).

The bacterial response to naturally occurring, seasonal inputs of POC has been documented in various studies (Lochte 1992, Pfannkuche 1993, Pfannkuche et al. 1999). It is first detectable as an intensification of metabolic activity, reflected in adenosine triphosphate concentration (Graf 1989) and extracellular enzyme production (Boetius \& Lochte 1994). The extracellular hydrolysis of $\mathrm{OM}$ is a prerequisite for bacterial cells to gain access to macromolecules, since only low molecular weight compounds can be transported across bacterial membranes (Benz 1985). Bacterial growth may follow enzyme production provided that the exploitable energy of the substrate is sufficiently high (Boetius \& Lochte 1994, 1996). Other small-sized organisms, such as protozoa and foraminifera, are also highly responsive to food pulses and may undergo changes in density (Gooday \& Rathburn 1999) and species composition (Lambshead \& Gooday 1990) or show episodic recruitment of opportunistic species (Ohga \& Kitazato 1997). The response of benthic metazoans in terms of population dynamics has been more difficult to establish, perhaps because of their slower turnover rates (Gooday 2002). On the timescale of several months, however, metazoan communities show shifts in their structure in relation to upper-ocean conditions and food supply (Ruhl \& Smith 2004, Sellanes et al. 2007, Ruhl et al. 2008).

In recent years, stable isotope techniques have enabled the direct observation of POC utilization by benthic communities. The role of each benthic component in the short-term $\mathrm{C}$ processing can be assessed quantitatively using labelled substrates as food sources. Previous labelling studies demonstrated that benthic $\mathrm{C}$ processing can be rapid in deep-sea sediments (Blair et al. 1996, Moodley et al. 2002, 2005, Witte et al. 2003a,b). Tracer uptake by faunal groups varies with environmental setting and community structure (Moodley et al. 2000, Witte et al. 2003b, Woulds et al. 2007). Despite the attempts to categorise previous observations in order to predict benthic response patterns in unexplored regions (Woulds et al. 2009), the factors that control the speed, magnitude, and relative importance of the different food web components in contrasting oceanic environments remain unclear. Nonetheless, it is apparent that bacteria typically dominate $\mathrm{C}$ mineralization in deep-sea sediments and that temperature plays a key role in limiting the overall benthic response (Moodley et al. 2005). The quantity and quality of available substrates have also been suggested to affect $C$ processing patterns in bathyal and abyssal sediments (Bühring et al. 2006, Aspetsberger et al. 2007). These findings are not entirely surprising considering the wealth of studies that document interacting effects between temperature and substrate supply in limiting the growth of heterotrophic bacterial communities in other marine environments (reviewed by Pomeroy \& Wiebe 2001, Apple et al. 2006).

The present study examined the response of a bathyal benthic community to an influx of OM under mesotrophic conditions (Kaariainen 2006) and subzero temperatures. A food pulse was simulated by adding ${ }^{13} \mathrm{C}$-labelled diatoms to undisturbed sediment cores retrieved from the deep Faroe-Shetland Channel (FSC). The mineralization of the added $\mathrm{C}$ by the benthic community was followed for $6 \mathrm{~d}$ while the uptake of tracer by the different food web components was measured on 2 sampling intervals (Days 3 and 6). The progress of the benthic response and the changes in BGE during the incubation were evaluated by the release of dissolved inorganic ${ }^{13} \mathrm{C}\left(\mathrm{DI}^{13} \mathrm{C}\right)$ in the overlying water and by the incorporation of ${ }^{13} \mathrm{C}$-uptake into the biomass of bacteria, metazoan macrofauna, and meiofaunal-sized nematodes.

\section{MATERIALS AND METHODS}

Study site. The experiment was carried out in May 2007 on FRV 'Scotia' (Marine Scotland). The FSC is a deep-water channel separating the Faroe Plateau from the Scottish shelf and is a major pathway through which Arctic bottom water escapes to the south (Fig. 1) (Turrell et al. 1999). The sampling station was located at $1080 \mathrm{~m}$ in the FSC $\left(61^{\circ} 13^{\prime} 88^{\prime \prime} \mathrm{N}, 2^{\circ} 40^{\prime} 62^{\prime \prime} \mathrm{W}\right)$ (Fig. 1). The sediment type was muddy sand with some gravel, and the grain size ranged from very fine to medium (Bett 1997). OC content in the top centimetre was $0.2 \%$. Bottom water oxygen content averaged $306 \pm 6.5 \mu \mathrm{mol} \mathrm{l}^{-1}( \pm \mathrm{SD}, \mathrm{n}=9)$. Bottom water temperature and salinity at the time of sampling were $-0.7^{\circ} \mathrm{C}$ and 34.9, respectively.

Algal culture. The cosmopolitan chain-forming diatom Chaetoceros radicans (CCMP, Bigelow Marine Laboratories; cell size: $6 \mu \mathrm{m}$ diam.) was cultured at $15^{\circ} \mathrm{C}$ (16 h light:8 h dark cycle) in artificial seawater (Grasshoff et al. 1999) amended with $\mathrm{f} / 2$ medium 


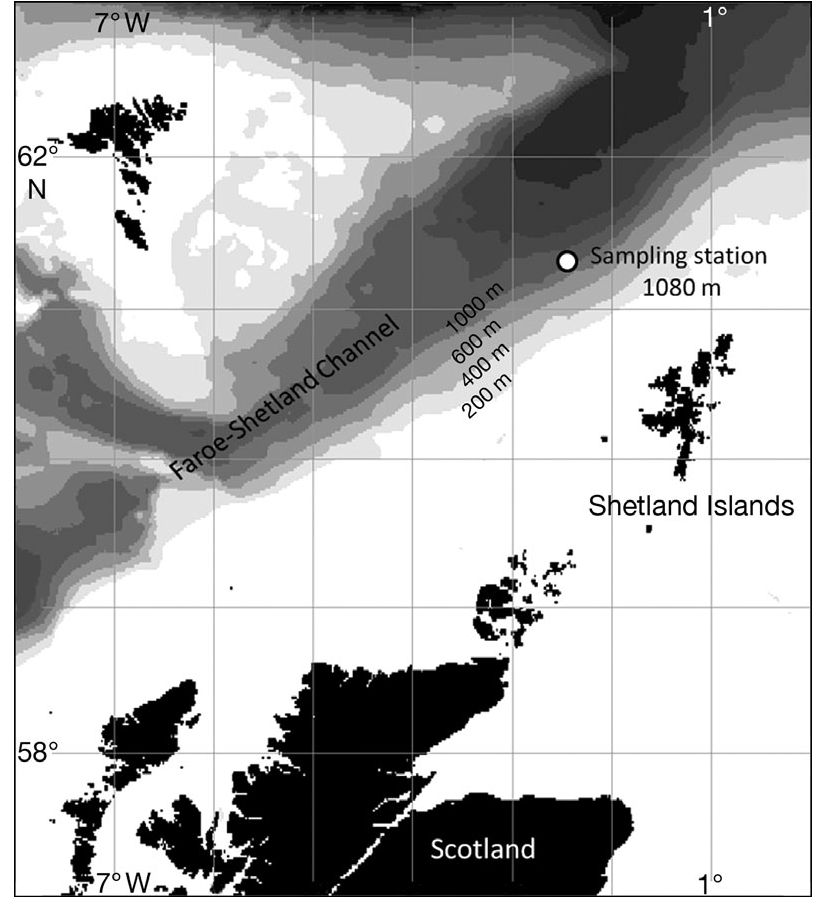

Fig. 1. Study area and location of sampling station (produced on the GEBCO Digital Atlas software; www.gebco.net)

(CCMP) and ${ }^{13} \mathrm{C}$-bicarbonate (99 atom $\%{ }^{13} \mathrm{C}$-enriched $\mathrm{NaHCO}_{3}$; Cambridge Isotope Laboratories). The algal material was harvested after $3 \mathrm{wk}$ by centrifugation $(1400 \times g, 15 \mathrm{~min})$ and washed 3 times with sterilefiltered $(0.2 \mu \mathrm{m})$ seawater to remove excess $\mathrm{NaH}^{13} \mathrm{CO}_{3}$ and any dissolved organic ${ }^{13} \mathrm{C}$ exuded by the diatoms. The harvest was frozen in liquid nitrogen to avoid cell rupture and stored at $-80^{\circ} \mathrm{C}$ until freeze-drying. The dried algae contained 46 atom $\%{ }^{13} \mathrm{C}$ (measured on a Flash EA 1112 Series Elemental Analyser connected via a Conflo III to a Delta ${ }^{\text {Plus }}$ Advantage isotope ratio mass spectrometer; Thermo Finnigan). Before use in the pulse-chase experiment, the algae were suspended in $0.2 \mu \mathrm{m}$ filtered seawater. Despite thorough rinsing of the algal material during harvesting, the possibility of simultaneous introduction of ${ }^{13} \mathrm{C}$-dissolved organic carbon (DOC) into the cores cannot be excluded. The amount of ${ }^{13} \mathrm{C}$-DOC added to our experimental cores was not quantified. Nonetheless, a similar ${ }^{13} \mathrm{C}$ study has previously demonstrated that this artefact contributes $<5 \%$ of the total added ${ }^{13} \mathrm{C}$ (Andersson et al. 2008).

Sampling and experimental design. A Bowers \& Connelly maxicorer equipped with 8 coring mechanisms was used for sediment core retrieval. The sediment cores (10 cm internal diameter, i.d.) used in the incubation experiment $(\mathrm{n}=15)$ were collected from 3 maxicorer deployments. In order to simulate the sedi- mentation of POC, $60 \mathrm{mg}$ of freeze-dried Chaetoceros radicans, equivalent to $0.5 \mathrm{~g} \mathrm{OC} \mathrm{m}^{-2}$, were carefully added to 12 experimental cores with a long pipette (separate for each core) in order to achieve even distribution of algae on the sediment surface. Bottom water temperature was maintained by incubating the cores in a chilling unit. Three control cores (without labelled algae addition) were also incubated together with the experimental cores and served for recording the background sediment community oxygen consumption (SCOC) as well as the determination of the background $\delta^{13} \mathrm{C}$ of bacterial phospholipid fatty acids (PLFA). All cores were sealed with lids to prevent gas exchange with air and incubated at ambient temperature (range: -1 to $0^{\circ} \mathrm{C}$ ) in the dark for $6 \mathrm{~d}$. The overlying water was sampled for oxygen and $\mathrm{DI}^{13} \mathrm{C}$ measurements at regular intervals (Time 0 and then after 1,2 , 3,4 , and $6 \mathrm{~d}$ ). Oxygen concentration was measured onboard using Winkler titration and did not decrease more than $20 \%$ of the initial value (Hulth et al. 1994). The $\mathrm{DI}^{13} \mathrm{C}$ samples were filtered through a $0.2 \mu \mathrm{m}$ syringe filter into $12 \mathrm{ml}$ gas-tight glass vials sealed with rubber septa and poisoned with $100 \mu$ of saturated $\mathrm{HgCl}_{2}$ solution to stop bacterial activity. The samples were kept at $4^{\circ} \mathrm{C}$ until analysis. Six replicate cores were sectioned after 3 and $6 \mathrm{~d}$ of incubation. For each experimental time, 3 cores were sampled for faunal analysis, and the remaining 3 were used for bacterial PLFA analysis. Control cores were sectioned on Day 6 and samples were used for the determination of background bacterial PLFA isotopic signatures.

Faunal samples were taken from 0 to 2, 2 to 5 , and 5 to $10 \mathrm{~cm}$. Part of the slice was kept for meiofaunal (defined here as animals passing through $250 \mu \mathrm{m}$ and retained on a $32 \mu \mathrm{m}$ mesh sieve) stable isotope analysis with the aid of a subcore $(2.5 \mathrm{~cm}$ i.d.), and the rest was sieved through a $250 \mu \mathrm{m}$ mesh sieve to retain macrofauna specimens. Meio- and macrofauna samples were stored in $10 \%$ formalin until picking and identification (in the case of macrofauna) under a binocular microscope. Detailed methodology of the macrofaunal analysis and results on the macrofaunal community structure, biomass, and ${ }^{13} \mathrm{C}$ uptake at the family or genus level are presented elsewhere (Gontikaki et al. in press). In the case of meiofauna (nematodes), only the 0 to $2 \mathrm{~cm}$ depth layer was analysed based on the macrofaunal vertical distribution pattern in the FSC, which suggested a particularly shallow dwelling community $(90 \%$ of macrofaunal animals recovered from the 0 to $2 \mathrm{~cm}$ layer) (Gontikaki et al. in press). A minimum of 100 nematodes per sample were picked to ensure sufficient biomass for a reliable isotope analysis. The nematode biomass (OC content) was measured directly from the area counts given in the standard output of the isotope ratio mass spectrometer. 
Sediment samples used for bacterial PLFA analysis were taken from 0 to $0.5,0.5$ to 1,1 to 2,2 to 3,3 to 5 , and $>5 \mathrm{~cm}$ horizons. The samples were placed in glass vials and stored at $-20^{\circ} \mathrm{C}$ until analysis.

DI ${ }^{13} \mathbf{C}$ analysis. The $\mathrm{C}$ isotope ratio of dissolved inorganic carbon (DIC) was determined following its quantitative conversion to carbon dioxide $\left(\mathrm{CO}_{2}\right)$ by acidification. Of the samples, $2 \mathrm{ml}$ were added to $12 \mathrm{ml}$ Exetainers ${ }^{\circledR}$ (Labco). The Exetainers ${ }^{\circledR}$ were capped and then flush filled with $\mathrm{He}$ at a flow rate of $100 \mathrm{ml}$ $\min ^{-1}$ for $5 \mathrm{~min}$. $100 \mu \mathrm{l}$ of $1.3 \mathrm{M}$ phosphoric acid was injected into each sample through the rubber septum in the cap. The head space of the Exetainer ${ }^{\circledR}$ containing the released $\mathrm{CO}_{2}$ was then transferred to a second Exetainer ${ }^{\circledR}$ as described by Midwood et al. (2006). The $\mathrm{C}$ isotope ratio of the $\mathrm{CO}_{2}$ in this second Exetainer ${ }^{\circledR}$ was then analysed using a Gas-bench II connected to a

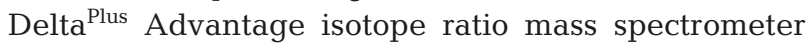
(both Thermo Finnigan). The $\mathrm{C}$ isotope ratios, all expressed relative to Vienna PeeDee Belemnite (VPDB), were calculated with respect to $\mathrm{CO}_{2}$ reference gasses injected with every sample and traceable to International Atomic Energy Agency (IAEA) reference material NBS 19 TS-Limestone. Through use of the Valco valve and a sample loop within the gas bench and the instrument software, each Exetainer ${ }^{\circledR}$ was sampled 9 times, of which the last 5 values were averaged to give a single sample value. Repeated analysis of a quality control standard gas indicated that the precision of the gas bench for analyzing $\delta^{13} \mathrm{C}$ of $\mathrm{CO}_{2}$ at a concentration of $450 \mathrm{ppm}$ in exetainers was $-35.03 \pm$ $0.24 \%$ (mean $\pm \mathrm{SD}, \mathrm{n}=65$ ). The amount of DIC in the sample was determined from the mean amplitude of the last 5 replicate sample peaks compared against a standard curve constructed from a range of similarly treated solutions.

Lipid extraction and separation. Total lipids were extracted following the Bligh \& Dyer (1959) extraction procedure as modified by White et al. (1979). Approximately $9 \mathrm{~g}$ of freeze-dried sediment was weighed out in glass centrifuge tubes with a PTFE lined cap. The lipids were extracted using a single phase extractant consisting of chloroform, methanol, and citrate buffer (1:2:0.8 v/v/v) for $2 \mathrm{~h}$. The total lipid extract was fractionated into polarity classes on silicic acid columns (6 ml ISOLUTE SIS PE columns; International Sorbent Technology) by sequential elution with chloroform (neutral lipids), acetone (glycolipids), and methanol (phospholipids). The phospholipids were transmethylated under alkaline methanolysis to yield fatty acid methyl esters (FAME).

FAME quantification and identification. Individual FAME were identified and quantified on a Shimadzu GC-2014 gas chromatograph flame ionization detector equipped with a Zebron ZB-WAX fused silica capillary column (30 $\mathrm{m} \times 0.25 \mathrm{~mm}$ i.d.) with helium as the carrier gas. The oven temperature was programmed to rise from 50 to $160^{\circ} \mathrm{C}$ at $25^{\circ} \mathrm{C} \mathrm{min}{ }^{-1}$, then 160 to $240^{\circ} \mathrm{C}$ at $4^{\circ} \mathrm{C} \mathrm{m^{-1 }}$ and then hold for $10 \mathrm{~min}$. Quantification was performed by comparing peak areas to an internal standard (19:0). Individual components were identified by reference to standards (Sigma-Aldrich, Matreya). Repeated analysis of a 28 component standard sample gave a mean \% SD across all peaks of $1.02 \%$.

FAME stable carbon isotope ratios. The isotopic composition of individual FAME was determined using a GC Trace Ultra with combustion column attached via a GC Combustion III to a Delta V Advantage isotope ratio mass spectrometer (all Thermo Finnigan). Samples $(2 \mu \mathrm{l})$ were injected in splitless mode onto a J\&W Scientific HP-5 column, $50 \mathrm{~m}$ length, $0.2 \mathrm{~mm}$ i.d. with a film thickness of $0.33 \mu \mathrm{m}$ (Agilent Technologies). Running conditions were as described by Paterson et al. (2006). The $\mathrm{C}$ isotope ratios were calculated with respect to a $\mathrm{CO}_{2}$ reference gas injected with every sample and traceable to IAEA reference material NBS 19 TS-Limestone. Repeated analysis, over a 2 mo period, of the $\delta^{13} \mathrm{C}$ value of a $\mathrm{C}_{19}$ FAME internal standard gave a SD of $1.11 \%$ o $(n=18)$.

Calculations. Carbon isotopes are expressed in the delta notation $(\delta \%$ ) relative to a reference according to:

$$
\delta^{13} \mathrm{C}(\%)=R_{\text {sample }} / R_{\mathrm{VPDB}} \times 1000
$$

where $R_{\text {sample }}$ and $R_{\mathrm{VPDB}}$ are the ${ }^{13} \mathrm{C}:{ }^{12} \mathrm{C}$ ratios of the sample and the international reference material for carbon (VPDB) respectively $\left(R_{\mathrm{VPDB}}=0.0112372\right)$. In order to obtain the actual PLFA $\delta^{13} \mathrm{C}$ values, the isotope ratios of FAME were corrected for the extra $\mathrm{C}$ in the methyl group that was added during derivatization according to Crossman et al. (2004).

The absolute amount of incorporated ${ }^{13} \mathrm{C}$ (total uptake, $I$ ) was calculated as the product of excess ${ }^{13} \mathrm{C}(E)$ and concentration of DIC, specimen biomass or specific bacterial PLFA concentration. Excess ${ }^{13} \mathrm{C}(E)$ is given by the difference in the fraction ${ }^{13} \mathrm{C}$ in the sample $\left(F_{\text {sample }}\right)$ and the background $\left(F_{\text {background }}\right)$ :

$$
E=F_{\text {sample }}-F_{\text {background }}
$$

where $F=\frac{{ }^{13} C}{{ }^{13} C+{ }^{12} C}=\frac{R}{R+1}$

and $\quad R=\left(\frac{\delta^{13} C}{1000}+1\right) \times R_{V P D B}$

The background $\delta^{13} \mathrm{C}$ of DIC was taken as the value measured at Time 0 in the experimental cores in order to correct for any contamination of ${ }^{13} \mathrm{C}$-bicarbonate by the added diatoms (Moodley et al. 2005).

Label incorporation into bacterial biomass, was based on the ${ }^{13} \mathrm{C}$ labelling of the most common bacterial PLFA in all cores and depth horizons (i15:0, a15:0, and i16:0) (Boschker \& Middelburg 2002). The fatty 
acid 18:1(n-7) is considered to be primarily of bacterial origin; however, it is also present in Chaetoceros radicans (D. J. Mayor unpubl. data). The effect of incorporating 18:1(n-7) into the calculations of bacterial uptake is examined. For each bacterial fatty acid, label incorporation was calculated as:

$$
I_{\mathrm{PLFA}}=E_{\mathrm{PLFA}} \times \mathrm{PFLA}_{\text {concentration }}
$$

Subsequently, incorporation into bacterial biomass was calculated based on Middelburg et al. (2000) as:

$$
I=\sum \frac{I_{P L F A}}{a \times b}
$$

where $a$ is the average PLFA concentration in bacteria (0.056 g PLFA C g ${ }^{-1}$ of $\mathrm{C}$ biomass; Brinch-Iversen \& King 1990) and $b$ is the fraction of the bacterial PLFA considered here that are encountered in sediments from the FSC $(0.11$; calculated from the \% of i15:0, a15:0, i16:0 in the present study, data not shown). The total algal $\mathrm{C}\left({ }^{12} \mathrm{C}+{ }^{13} \mathrm{C}\right)$ recovered from bacteria, fauna, and the DIC pool was calculated as the quotient of the total uptake $I$ and the fractional abundance of ${ }^{13} \mathrm{C}$ in the algae (0.46). Bacterial biomass was calculated from the concentration of bacteria-specific biomarkers (i15:0, a15:0, i16:0) and the conversion factors used in Eq. (4).

Bacterial growth efficiency (BGE). BGE is defined as the fraction of assimilated $\mathrm{OC}$ that is channelled towards growth according to:

$$
\mathrm{BGE}=\frac{\mathrm{BP}}{\mathrm{BP}+\mathrm{BR}}
$$

where BP is bacterial production and $\mathrm{BR}$ the bacterial respiration. In the present study, BGE was calculated based on ${ }^{13} \mathrm{C}$ uptake data and represents the growth efficiency when bacteria consume the added material. BP is thus the total algal $\mathrm{C}$ uptake (see 'Calculations' above) and $\mathrm{BR}$ is the bacterial respiration of algal $\mathrm{C}$ (= total algal DIC - algal DIC due to faunal respiration). Macrofaunal and nematode biomass-specific respiration rates $\left(R_{\text {macro }}\right.$ and $\left.R_{\text {nem }}\right)$ were estimated using the allometric equations: $\quad R_{\text {macro }}=7.4 \times 10^{-3} \times W^{-0.24}$ (Mahaut et al. 1995) and $R_{\mathrm{nem}}=0.0164 \times$ $W^{-0.1456}$ (Soetaert et al. 1997, Heip et al. 2001), respectively, where $W$ is the individual organism weight ( $\mathrm{mg} \mathrm{C})$. Corrections for temperature were based on Gillooly et al. (2001).

Statistical analysis. The oxygen flux within each core was calculated from the slope of the linear regression of oxy- gen concentration against time $(0,2,3,6$ d) (Fig. 2). Due to analytical problems encountered on Days 1 and 4 , data from these days were excluded from the analysis.

The increase in algal-derived DIC concentration with time was best described by an exponential curve $\left(y=b \times e^{a x}\right)$. The effect of time on algal-derived DIC production was tested by means of linear regression after the natural log transformation of the DIC concentration data. Statistical tests (ANOVA or the nonparametric equivalent where the ANOVA assumptions were not met) were carried out using SigmaStat ${ }^{\circledR} 11.0$ (Systat Software). Values are given as means \pm SD.

\section{RESULTS}

\section{Sediment community oxygen consumption (SCOC)}

The bottom water oxygen content obtained from the control and experimental cores (before initiation of the incubation) averaged $306 \pm 6.3 \mu \mathrm{mol} \mathrm{O}_{2} \mathrm{l}^{-1}(\mathrm{n}=15)$. Background SCOC, as determined from the 3 control cores averaged $2.0 \pm 1.5 \mathrm{mmol} \mathrm{m}^{-2} \mathrm{~d}^{-1}(\mathrm{n}=3)$. SCOC in experimental cores $\left(3.2 \pm 1.4 \mathrm{mmol} \mathrm{m}^{-2} \mathrm{~d}^{-1}, \mathrm{n}=6\right)$ after $6 \mathrm{~d}$ of incubation was not significantly different from the SCOC in controls (Kruskal-Wallis test, $\mathrm{p}=0.381$ ).

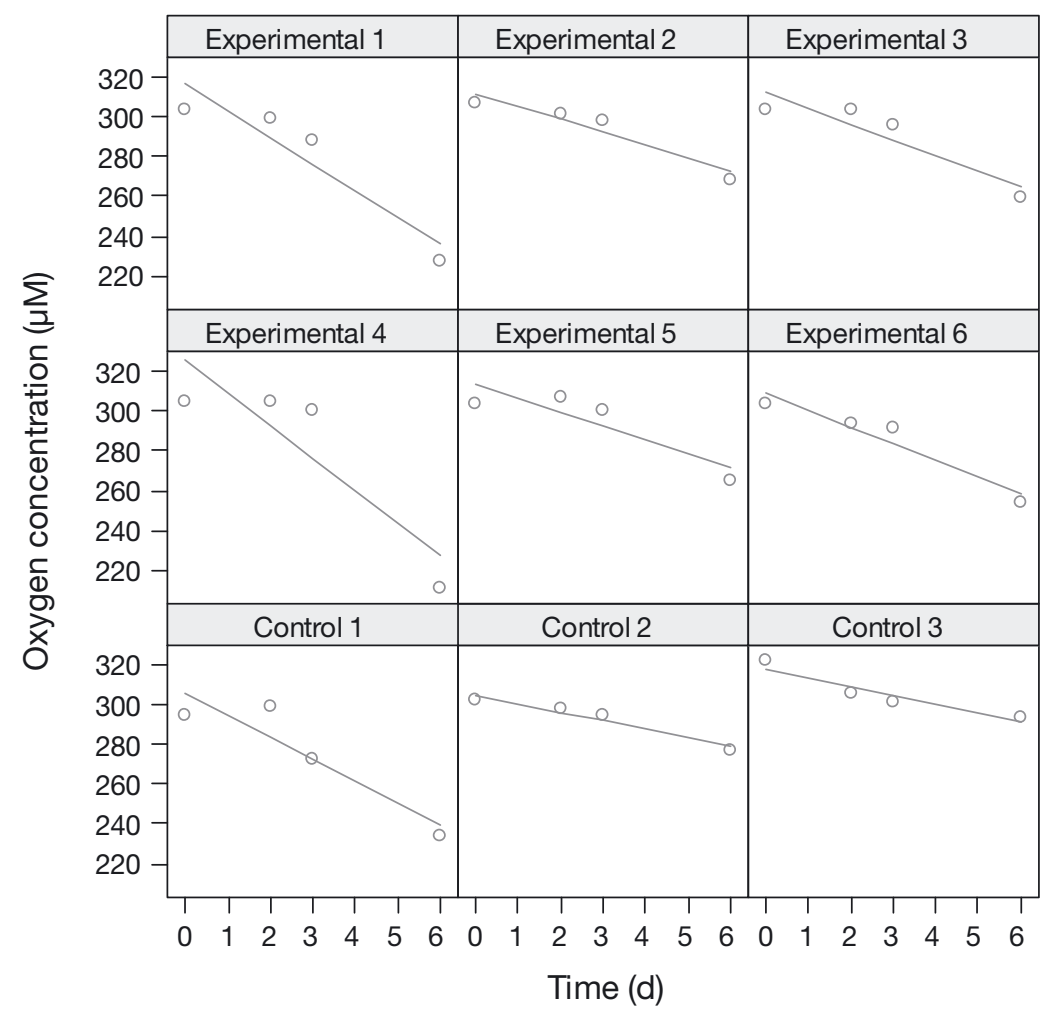

Fig. 2. Decrease in oxygen concentration $(\mu \mathrm{M})$ with time in control and experimental replicate cores. The slope of each linear regression was used to calculate the oxygen flux $\left(\mathrm{mmol} \mathrm{O}_{2} \mathrm{~m}^{-2} \mathrm{~d}^{-1}\right)$ within each core 


\section{Algal C mineralization and uptake}

The quantity of the algal-derived $\mathrm{C}$ that was mineralized increased significantly $(F=171.1, \mathrm{df}=1, \mathrm{p}<0.001)$ over the duration of the experiment (Fig. 3). In quantitative terms, a total of $3.77 \mathrm{mg} \mathrm{C} \mathrm{m}^{-2}(0.75 \%)$ and $43.66 \mathrm{mg}$ $\mathrm{C} \mathrm{m}^{-2}(9 \%)$ of the added $\mathrm{C}$ was released as DIC after 3 and $6 \mathrm{~d}$ of incubation, respectively (Table 1).

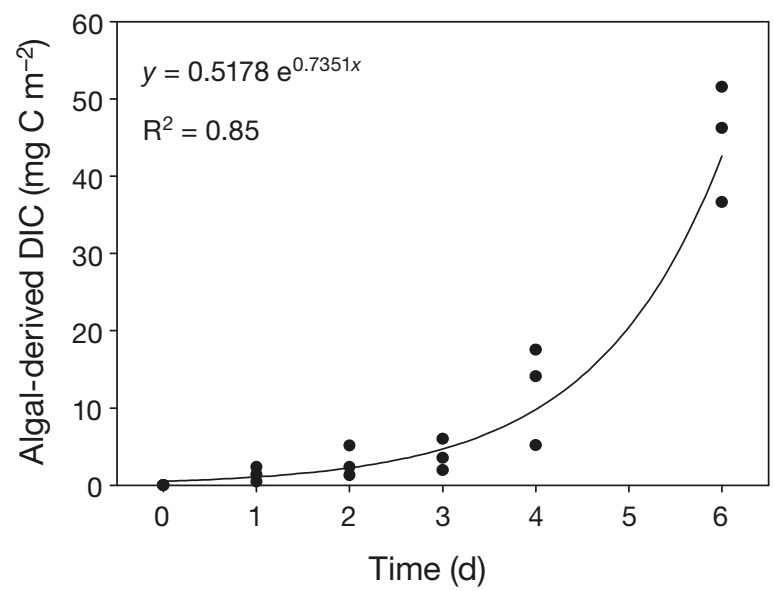

Fig. 3. Release of dissolved inorganic carbon (DIC) deriving from the consumption of the added diatoms with time

Table 1. Total amount of algal C (means $\pm \mathrm{SD}$ ) incorporated in bacteria, meiofauna, and macrofauna $\left(\mathrm{mg} \mathrm{C} \mathrm{m}^{-2}\right)$, total respiration $\left(\mathrm{mg} \mathrm{C} \mathrm{m}^{-2}\right)$, and respiration partitioning among the measured food-web compartments (\%). Data on macrofaunal uptake are from Gontikaki et al. (in press). The biomass (means $\pm \mathrm{SD}$ ) of each investigated compartment is given for comparison: bacteria $4.0 \pm 0.2 \mathrm{~g} \mathrm{C} \mathrm{m}^{-2}(0$ to $10 \mathrm{~cm})$, meiofauna $0.04 \pm 0.02 \mathrm{~g} \mathrm{C} \mathrm{m}^{-2}$ (0 to $\left.2 \mathrm{~cm}\right)$, macrofauna $0.7 \pm 0.6 \mathrm{~g} \mathrm{C} \mathrm{m}^{-2}$ $(0$ to $10 \mathrm{~cm})$

\begin{tabular}{|c|c|c|c|}
\hline & \multicolumn{2}{|c|}{ Algal $\mathrm{C}$ budget (mg C m${ }^{-2}$ ) } & $\begin{array}{c}\text { Respiration } \\
(\%)\end{array}$ \\
\hline Bacteria & $14.9 \pm 7.2$ & $17.5 \pm 3.0$ & 90.1 \\
\hline Meiofauna & $0.01 \pm 0.01$ & $0.02 \pm 0.01$ & 1.2 \\
\hline Macrofauna & $0.8 \pm 0.9$ & $2.0 \pm 1.9$ & 8.7 \\
\hline Total respiration & $3.8 \pm 2.0$ & $43.7 \pm 7.4$ & \\
\hline
\end{tabular}

The total amount of added $\mathrm{C}$ that was mineralized and incorporated into bacterial and faunal biomass (hereafter mentioned as total processed C) reached 19.5 and $63 \mathrm{mg}$ $\mathrm{C} \mathrm{m}^{-2}$ after 3 and $6 \mathrm{~d}$, representing 3.9 and $12.6 \%$ of the total added $\mathrm{C}$ respectively. The majority of processed $\mathrm{C}$ after $3 \mathrm{~d}(\sim 77 \%)$ was incorporated into bacterial biomass, whereas the bulk of the processed $\mathrm{C}$ after $6 \mathrm{~d}$ of incubation ( 69\%) was retrieved from the DIC pool (Fig. 4). The total amount of added $\mathrm{C}$ that was recovered from the investigated food web compartments is presented in Table 1. Bacterial uptake averaged $14.9 \pm 7$ and $17.5 \pm 3 \mathrm{mg} \mathrm{C}$ $\mathrm{m}^{-2}$ after 3 and $6 \mathrm{~d}$, respectively $(15.3 \pm 5.8$ and $16.6 \pm$ $4.2 \mathrm{mg} \mathrm{C} \mathrm{m}^{-2}$ after 3 and $6 \mathrm{~d}$ when 18:1(n-7) is included in the calculations) (Table 1). The difference in bacterial uptake between Days 3 and 6 was not significant (Kruskal-Wallis test, $\mathrm{p}=0.667$ ). Approximately 95\% of the total bacterial uptake took place at 0 to $0.5 \mathrm{~cm}$ in both experimental times, although uptake was detectable down to $2 \mathrm{~cm}$. Incorporation of ${ }^{13} \mathrm{C}$ into the bacterial biomarkers i15:0, a15:0, and i16:0 is presented in Fig. 5.

Among meiofaunal taxa, only nematodes from 0 to $2 \mathrm{~cm}$ were analysed for ${ }^{13} \mathrm{C}$ uptake. Nematode abundance averaged $306 \pm 74$ ind. $10 \mathrm{~cm}^{-2}$. The abundance of other metazoan meiofaunal taxa was extremely low (only 3 to 4 ind. recovered from each sample), and thus their contribution to $\mathrm{C}$ processing was considered to be negligible. Foraminifera and other protozoa were not included in the analysis, and thus their contribution to the total processed $\mathrm{C}$ is unknown. Nematode uptake contributed 0.05 and $0.02 \%$ to the total processed algal $\mathrm{C}$ after 3 and $6 \mathrm{~d}$, respectively (Fig. 4). The difference in nematode uptake between the 2 sampling times was not statistically significant $(F=0.427, \mathrm{df}=1, \mathrm{p}=0.56)$. Macrofauna were responsible for $99 \%$ of the metazoan uptake; however, the overall contribution of metazoan fauna to $C$ processing was relatively low (4.2 and 3.2\% of the total processed algal-derived $C$ on Days 3 and 6 , respectively). Macrofaunal uptake on Day 3 was not significantly different from that on Day 6 (Gontikaki et al. in press).
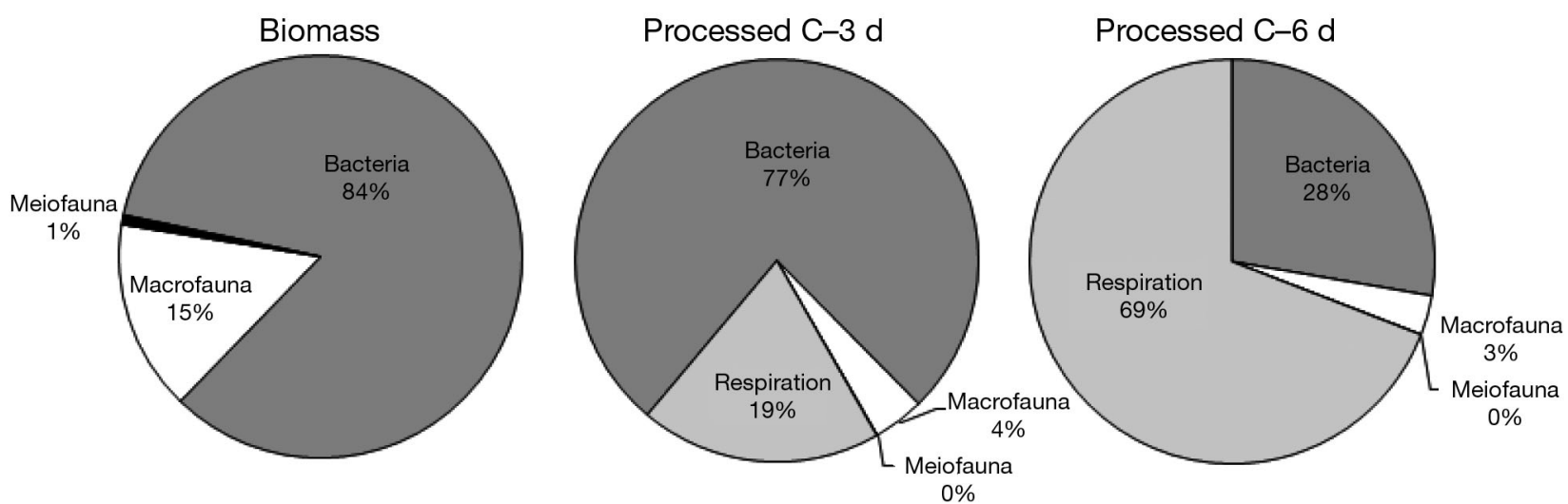

Fig. 4. Proportional division of biomass and processed carbon (C) after 3 and $6 \mathrm{~d}$ among the different benthic compartments 


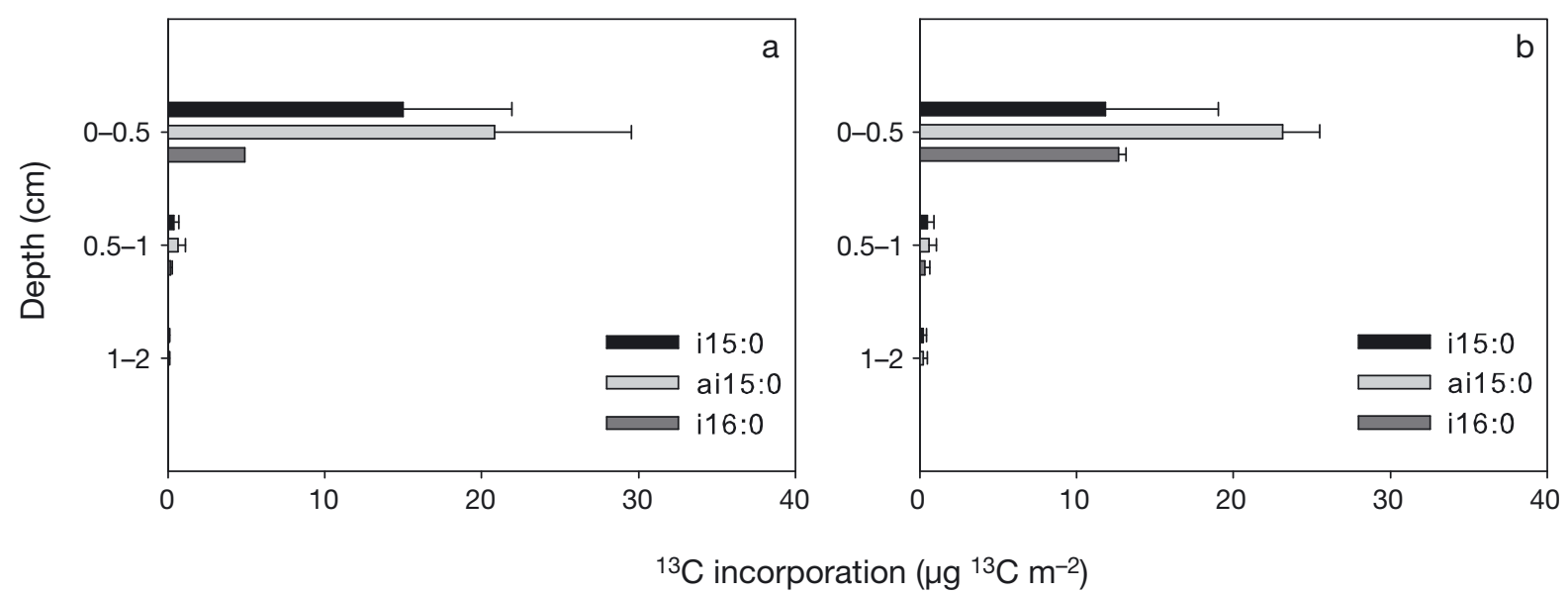

Fig. 5. Incorporation of ${ }^{13} \mathrm{C}$ into bacterial phospholipid fatty acids (PLFA) at 0 to $0.5,0.5$ to 1 , and 1 to $2 \mathrm{~cm}$ after (a) $3 \mathrm{~d}$ and (b) $6 \mathrm{~d}$ of incubation. No tracer was detected in bacterial PLFA at deeper horizons. Error bars represent \pm SD $(n=3)$

\section{Faunal respiration and $\mathrm{BGE}$}

Macrofaunal and nematode biomass-specific respiration rates were 2.84 and $0.35 \mathrm{mg} \mathrm{C} \mathrm{m}^{-2} \mathrm{~d}^{-1}$, respectively. These values represented 8.7 and $1.2 \%$ of SCOC in experimental cores (SCOC was converted to $\mathrm{C}$ units assuming a respiratory quotient $\mathrm{RQ}=0.85$; Smith 1987). Accordingly, the macrofaunal and nematode algal $\mathrm{C}$ respiration for each experimental time was assumed to be 8.7 and $1.2 \%$ of the total algalderived DIC production, respectively. Bacterial respiration was thus assumed to account for the remaining $90.1 \%$ of the total respiration. It should be noted that this is a maximum value since not all faunal compartments are considered in the analysis. The BGE estimated from the bacterial algal $\mathrm{C}$ uptake and respiration after $3 \mathrm{~d}$ was $0.8 \pm 0.04$. This value dropped to $0.3 \pm$ 0.07 when calculated from the bacterial processed $\mathrm{C}$ budget after $6 \mathrm{~d}$.

\section{DISCUSSION}

\section{Methodological considerations}

It is acknowledged that ex situ incubations may involve artefacts related to core warming and decompression during core retrieval (Glud et al. 1994, 1998, Hall et al. 2007). The extremely cold temperatures prevailing in much of the water overlying the $\mathrm{FSC}\left(<2{ }^{\circ} \mathrm{C}\right.$ below $450 \mathrm{~m}$ ) in combination with rapid onboard handling (typically $\sim 15$ min for 8 cores) ensured minimal warming of the sediment cores during their collection and retrieval. Decompression effects are more pronounced in sediments $>2000 \mathrm{~m}$, and it is generally accepted that at or above $1000 \mathrm{~m}$ core recovery artefacts seem to be more or less negligible (Hensen et al. 2006). Labelling experiments conducted both in situ and ex situ did not show any systematic differences down to $1000 \mathrm{~m}$ depth in the Arabian Sea (Woulds et al. 2007, Andersson et al. 2008). We are therefore confident that the sampling procedures and experimental conditions did not introduce major errors into the results of the present study.

\section{Benthic mineralization}

The background SCOC averaged $2.06 \mathrm{mmol} \mathrm{O}_{2} \mathrm{~m}^{-2}$ $\mathrm{d}^{-1}$. Individual rates ranged from 1.12 to $3.90 \mathrm{mmol} \mathrm{O}_{2}$ $\mathrm{m}^{-2} \mathrm{~d}^{-1}$ indicating a high degree of heterogeneity among replicates. Our oxygen uptake rates fall within the range of published SCOC rates in other warmer slope regions (1.1 to $2.5 \mathrm{mmol} \mathrm{O}_{2} \mathrm{~m}^{-2} \mathrm{~d}^{-1}$ at $\sim 1000 \mathrm{~m}$ and $9^{\circ} \mathrm{C}$ in the Goban Spur: Lohse et al. 1998; 2.6 to $3.4 \mathrm{mmol} \mathrm{O} \mathrm{m}^{-2} \mathrm{~d}^{-1}$ at $1300 \mathrm{~m}$ and $3.5^{\circ} \mathrm{C}$ in the North Pacific: Smith $1987 ; 2.4 \mathrm{mmol} \mathrm{O}_{2} \mathrm{~m}^{-2} \mathrm{~d}^{-1}$ at 330 to $915 \mathrm{~m}$ and 13 to $14^{\circ} \mathrm{C}$ in the western Mediterranean: Accornero et al. 2003), suggesting that, similar to the cold Arctic shelf sediments (Arnosti 1998, Glud et al. 1998, Kostka et al. 1999), low temperatures in the FSC do not inhibit OM mineralization rates.

The difference in SCOC between control and experimental cores was not statistically significant, possibly due to inter-core variability. However, there was an increasing trend in oxygen consumption in experimental cores, and an average of $45 \%$ more oxygen was consumed in the experimental cores compared to the controls after $6 \mathrm{~d}$ of incubation. If the elevated oxygen consumption in experimental cores was due to the 
remineralisation of the added material, then the difference between control and experimental cores should approximate the algal-derived DIC release. The difference in oxygen consumption between control and treatment cores equates to an average of $67 \mathrm{mg} \mathrm{C} \mathrm{m}{ }^{-2}$ after $6 \mathrm{~d}$, while the DIC release attributed to the added material was $44 \pm 7 \mathrm{mg} \mathrm{C} \mathrm{m}^{-2}$. This result suggests that the mineralization of the added substrate was responsible for the major part of the increase in oxygen consumption in experimental cores. A possible contribution to the difference between control and treatment could be due to priming effects (PE), i.e. the acceleration of the decomposition of stable (refractory) OM due to the addition of labile OM (Kuzyakov et al. 2000). The existence of $\mathrm{PE}$ in marine sediments has only recently been demonstrated experimentally in shallow-water ecosystems (van Nugteren et al. 2009). However, the enhancement of PE in oligotrophic systems (Guenet et al. 2010) means that these processes could also be of major importance in deep-sea ecosystems and merit further attention in future studies on $\mathrm{C}$ and nutrient cycling.

\section{Community response}

Comparison of total $\mathrm{C}$ processing rates, measured in different pulse-chase experiments, is problematic owing to different methodologies (e.g. amount of added $\mathrm{OM}$ ) and data analysis (i.e. which faunal groups were included in the $\mathrm{C}$ budget) in each study. However, rough comparisons are allowed based on that: (1) the amount of added OM in most pulse-chase experiments is in excess, and thus comparisons between benthic communities are based on their maximum capacity for $\mathrm{C}$ processing; and (2) total C processing rates are dominated by respiration rates, and thus the exclusion of uptake by a faunal group in the analysis is not expected to produce a significant error in the community $\mathrm{C}$ budget.

The total $\mathrm{C}$ processing rates in the FSC varied between 6.5 and $14.6 \mathrm{mg} \mathrm{C} \mathrm{m}^{-2} \mathrm{~d}^{-1}$, as estimated from the $\mathrm{C}$ budget at 0 to 3 and 3 to $6 \mathrm{~d}$, respectively (10.5 mg C $\mathrm{m}^{-2}$ estimated from the whole duration of the experiment). Witte et al. (2003b) found processing rates ranging between 4 and $8.4 \mathrm{mg} \mathrm{C} \mathrm{m}^{-2} \mathrm{~d}^{-1}$ in the Porcupine Abyssal Plain (PAP) calculated after 2.5, 8, and $23 \mathrm{~d}$ of experiment. A similar range of $\mathrm{C}$ processing rates has been observed in other cold $\left(<4^{\circ} \mathrm{C}\right)$ and deep settings: 4.2 and $7.9 \mathrm{mg} \mathrm{C} \mathrm{m}^{-2} \mathrm{~d}^{-1}$ at $2150 \mathrm{~m}$ in the NE Atlantic (Moodley et al. 2002, 2005); $6.9 \mathrm{mg} \mathrm{C} \mathrm{m}^{-2} \mathrm{~d}^{-1}$ at 1200 , and $10.36 \mathrm{mg} \mathrm{C} \mathrm{m}^{-2} \mathrm{~d}^{-1}$ at $1850 \mathrm{~m}$ in the Pakistan margin (Woulds et al. 2009). Higher processing rates have been observed at bathyal settings in the very productive Benguela upwelling system (12 to $25 \mathrm{mg} \mathrm{C} \mathrm{m}^{-2} \mathrm{~d}^{-1}$;
Aspetsberger et al. 2007) and under warm bottom water conditions such as the Sognefjord $\left(7^{\circ} \mathrm{C}, 17\right.$ to $19 \mathrm{mg} \mathrm{C} \mathrm{m}{ }^{-2} \mathrm{~d}^{-1}$; Witte et al. 2003a) and the eastern Mediterranean Sea $\left(13\right.$ to $14^{\circ} \mathrm{C}, 47$ to $68 \mathrm{mg} \mathrm{C} \mathrm{m}^{-2} \mathrm{~d}^{-1}$; Moodley et al. 2005, Bühring et al. 2006). An exception was observed when a very low OM pulse was added to sediments from the bathyal eastern Mediterranean: in that case the total $\mathrm{C}$ processing rate $\left(6 \mathrm{mg} \mathrm{C} \mathrm{m}^{-2} \mathrm{~d}^{-1}\right)$ resembled the rates measured in cold bathyal and abyssal environments (Bühring et al. 2006).

The importance of meiofauna in benthic $\mathrm{C}$ and energy flows has been acknowledged in several earlier studies (Kuipers et al. 1981, Heip et al. 1985, Coull 1999). Recent pulse-chase experiment studies, however, indicate a limited direct contribution of metazoan meiofauna (nematodes) to the short-term processing of fresh OM in both intertidal (Urban-Malinga \& Moens 2006, Franco et al. 2008) and deep-sea settings (Moodley et al. 2002, Witte et al. 2003b, Moens et al. 2007, Ingels et al. 2010). In the present study, the incorporation of diatom-derived OM into nematode biomass (15 $\mu \mathrm{g} \mathrm{C} \mathrm{m}^{-2}$ in $6 \mathrm{~d}$ ) was in the range of uptake rates calculated by Ingels et al. (2010) for a bacterial-derived food source $\left(11 \mu \mathrm{g} \mathrm{C} \mathrm{m}{ }^{-2}\right.$ after $7 \mathrm{~d}$ in Antarctic sediments). Differences between nematode $\mathrm{C}$ uptake in the aforementioned studies possibly arise due to differences in the organic substrates added (see Ingels et al. 2010). They may also be attributable to differences in sample processing techniques (e.g Moens et al. 1999), as well as the structure and functional diversity of nematode communities. It is apparent that the lack of knowledge on the life cycles, energy requirements, and food preferences of deep-sea nematodes has so far hampered the full exploitation of stable isotope labelling techniques in understanding the role of these organisms in deep-sea C cycling.

Macrofauna tend to rapidly ingest labelled material during the initial stages of pulse-chase experiments, after which the net content of ${ }^{13} \mathrm{C}$ may not increase (Woulds et al. 2009). As a result, uptake rates may appear artificially greater for shorter experiments. Comparisons between experiments may be allowed when the timescales considered are similar but should be regarded with caution (Gontikaki et al. in press). In the FSC, macrofaunal $\mathrm{C}$ uptake $\left(0.8 \mathrm{mg} \mathrm{C} \mathrm{m}^{-2}\right.$ after $3 \mathrm{~d})$ was evidently higher than macrofaunal uptake in Korsfjord (0.04 $\mathrm{mg} \mathrm{C} \mathrm{m}{ }^{-2}$ after $2 \mathrm{~d}$ at $7^{\circ} \mathrm{C}_{;}$Sweetman \& Witte 2008) despite the similar macrofaunal biomass estimates between the 2 sites. In contrast, macrofaunal uptake in this study was $9 \times$ lower than that measured at similar depth in Sognefjord $\left(7.2 \mathrm{mg} \mathrm{C} \mathrm{m}^{-2}\right.$ after $3 \mathrm{~d}$ at $7^{\circ} \mathrm{C}$; Witte et al. 2003a), although macrofaunal biomass was $3 \times$ lower in the latter location. These results demonstrate that total biomass and temperature differences between experimental sites can- 
not explain sufficiently macrofaunal reaction patterns to OM addition. Differences in the community structure and species composition as well as seasonal and ontogenetic variations in metabolic rates may help explain the observed variability in macrofaunal response.

The total quantity of algal $\mathrm{C}$ attributed to bacterial community respiration after $3 \mathrm{~d}\left(3.4 \pm 1.9 \mathrm{mg} \mathrm{C} \mathrm{m}{ }^{-2}\right)$ was lower than their $\mathrm{C}$ uptake $\left(14.9 \pm 7.0 \mathrm{mg} \mathrm{C} \mathrm{m}^{-2}\right)$. This response pattern can be explained based on bacterial energetics. The BGE of deep water bacteria is thought to relate to OM quality, with BGE being highest when the bacterial community is fuelled by labile compounds (Tamburini et al. 2003). Low BGE has been observed when bacteria are consuming refractory compounds and is thought to reflect the energy requirements of enzyme production for the hydrolysis of these compounds (Tamburini et al. 2003). The introduction of labelled algae to the sediment in our experiment potentially involves the simultaneous addition of labile low molecular weight DOC (LMWDOC), which is assimilated directly by bacteria resulting in high BGE. Indeed, the BGE estimated from ${ }^{13}$ C-uptake after $3 \mathrm{~d}$ averaged $0.81( \pm 0.04)$. Similarly high bacterial growth efficiencies have been calculated for marine bacterioplankton feeding on dissolved OM excreted by phytoplankton (0.5 to 0.8 ; del Giorgio \& Cole 1998). The second half of our experiment was characterised by increased ${ }^{13} \mathrm{C}$-respiration without a significant increase in the quantity of ${ }^{13} \mathrm{C}$ incorporated into bacterial biomass. The BGE estimated from the algal-derived processed $C$ after $6 \mathrm{~d}$ $(0.32 \pm 0.07)$ is typical for marine bacterioplankton feeding on phytoplanktonic detritus $(0.07$ to 0.5 ; del Giorgio \& Cole 1998). The hydrolysis of large compounds within the detritus pool by extracellular enzymes is a necessary step for the utilization of polymers by bacteria and has been suggested to represent a major expenditure of bacteria in natural aquatic systems (del Giorgio \& Cole 2000). The decrease in BGE in the second half of our experiment could possibly be explained by an increase in bacterial energy demand associated with the production of extracellular hydrolytic enzymes (Middelboe \& Sondergaard 1993, Middelboe et al. 1996). Supporting evidence towards this suggestion come from batch cultures of bacterioplankton in which the extracellular enzyme production increased when most of the labile DOC was consumed and larger particle fractions were increasingly utilized (Middelboe \& Sondergaard 1995). Assuming a low contribution of DOC to the total added algal $\mathrm{C}$ $(\sim 5 \%$; Andersson et al. 2008), the amount of added DOC ( $25 \mathrm{mg} \mathrm{C} \mathrm{m}^{-2}$ ) would be within the range of bacterial algal-derived $C$ processing observed over the first $3 \mathrm{~d}$ of experimentation (Table 1).
The pattern of low respiration-high assimilation observed in the FSC after $3 \mathrm{~d}$ has only been observed before in the Cretan Sea, when a low C load was added to the system (Bühring et al. 2006). In that case, however, the experiment was terminated after $1.5 \mathrm{~d}$, and a possible change in the reaction pattern from enhanced growth to enhanced respiration could not be confirmed. The change in BGE observed at the 2 sampling intervals in the present study more likely represents a continuum rather than an abrupt change and is probably universal during the initial stages of the OM degradation process. It seems that factors such as the amount of added OM (Bühring et al. 2006) and/or low temperature (the present study) may have resulted in the extension of the transition from high to low BGE so that it was captured in the aforementioned pulse-chase experiments. The present study showed that a relatively large part of bacterial metabolism may be directed towards growth in the initial steps of the degradation process of labile OM and that the timing of sampling is crucial for identifying such patterns. A change in the pattern of energy and $\mathrm{C}$ allocation would have direct consequences for the amount of energy available to higher trophic levels. However, the regulation of BGE in natural systems remains perplexing both at the cellular and the community level. For example, BGE has been shown to differ along gradients of productivity but also with the phylogenetic composition of the community (del Giorgio \& Cole 2000). Future pulse-chase experiments should thus cover a wide range of locations of differing environmental and trophic regimes, combining substrates of various quantities and qualities with various sampling times in order to provide further insight on the combination of factors that drive $\mathrm{C}$ processing in benthic communities.

\section{CONCLUSIONS}

A 2 phase sampling strategy provided important insights into how deep-sea bacteria respond to an influx of OM: BGE was apparently high during the first $3 \mathrm{~d}$. This was attributed to the consumption of the most labile, readily utilizable substrates provided at the outset of the experiment. The BGE estimated at the end of the experiment was much lower, potentially reflecting the increased energy requirements associated with the production of hydrolytic enzymes. We hypothesise that a transition from high to low BGE following the addition of OM is a common occurrence in deep-sea sediments. The rate of change is expected to be influenced by the local environment (e.g. temperature and productivity) and the nature of the organic substrate. 
Acknowledgements. We are grateful to Marine Scotland for providing ship time on FRV 'Scotia' and also the Captain and crew of FRV 'Scotia' for their assistance in sampling. Special thanks to G. Slesser, J. Dunn, and the rest of the seagoing scientists for their invaluable help during the cruises. We also thank H. Orr for the GC-FID analysis, M. Procee and G. Martin for the GC-C-IRMS analysis of our samples, and N. Lampadariou and L. Moodley for their assistance in meiofaunal sorting and stable isotope analysis. This project was funded by the ECOSUMMER Marie Curie Early-stage Training Site (MEST-CT-2005-020501). D.J.M. was funded by the Leverhulme Trust (F/00152/T; awarded to U.W.) and is currently funded by NERC (NE/G014744/1).

\section{LITERATURE CITED}

Accornero A, Picon P, de Bovee F, Charriere B, Buscail R (2003) Organic carbon budget at the sediment-water interface on the Gulf of Lions continental margin. Cont Shelf Res 23:79-92

Andersson JH, Woulds C, Schwartz M, Cowie GL, Levin LA, Soetaert K, Middelburg JJ (2008) Short-term fate of phytodetritus in sediments across the Arabian Sea oxygen minimum zone. Biogeosciences 5:43-53

Apple JK, del Giorgio PA, Kemp WM (2006) Temperature regulation of bacterial production, respiration and growth efficiency in a temperate salt-marsh estuary. Aquat Microb Ecol 43:243-254

Arnosti C (1998) Rapid potential rates of extracellular enzymatic hydrolysis in Arctic sediments. Limnol Oceanogr 43: $315-324$

Aspetsberger F, Zabel M, Ferdelman T, Struck U, Mackensen A, Ahke A, Witte U (2007) Instantaneous benthic response to different organic matter quality: in situ experiments in the Benguela upwelling system. Mar Biol Res 3: 342-356

Benz R (1985) Porin from bacterial and mitochondrial outer membrane. Crit Rev Biochem Mol 19(2):145-190

Bett BJ (1997) Atlantic margin environmental survey. Seabed survey of the shelf edge and slope west of Shetland, RSS 'Charles Darwin' Cruise 101C Leg 2, Cruise Report No. 7. Southampton Oceanography Centre, Southampton

Billett MSD, Lampitt RS, Rice AL, Mantoura RFC (1983) Seasonal sedimentation of phytoplankton to the deep-sea benthos. Nature 302:520-522

Blair NE, Levin LA, DeMaster DJ, Plaia G (1996) The shortterm fate of fresh algal carbon in continental slope sediments. Limnol Oceanogr 41:1208-1219

Bligh EG, Dyer WJ (1959) A rapid method of total lipid extraction and purification. Can J Physiol Pharmacol 37:911-917

Boetius A, Lochte K (1994) Regulation of microbial enzymatic degradation of organic matter in deep-sea sediments. Mar Ecol Prog Ser 104:299-307

Boetius A, Lochte L (1996) Effects of organic enrichment on hydrolytic potentials and growth of bacteria in deep-sea sediments. Mar Ecol Prog Ser 140:239-250

Boschker HTS, Middelburg JJ (2002) Stable isotopes and biomarkers in microbial ecology. FEMS Microbiol Ecol 40: 85-95

Brinch-Iversen J, King GM (1990) Effects of substrate concentration, growth state and oxygen availability on relationships among bacterial carbon, nitrogen and phospholipid phosphorus content. FEMS Microbiol Ecol 74:345-356

Bühring SI, Lampadariou N, Moodley L, Tselepides A, Witte U (2006) Benthic microbial and whole-community responses to different amounts of ${ }^{13} \mathrm{C}$-enriched algae: in situ experiments in the deep Cretan Sea (eastern Mediterranean). Limnol Oceanogr 51:157-165

Coull BC (1999) Role of meiofauna in estuarine soft-bottom habitats. Aust J Ecol 24:327-343

Crossman ZM, Abraham F, Evershed RP (2004) Stable isotope pulse-chasing and compound specific stable carbon isotope analysis of phospholipid fatty acids to assess methane oxidizing bacterial populations in landfill cover soils. Environ Sci Technol 38:1359-1367

> De La Rocha C, Passow U (2007) Factors influencing the sinking of POC and the efficiency of the biological carbon pump. Deep-Sea Res II 54:639-658

del Giorgio PA, Cole JJ (1998) Bacterial growth efficiency in natural aquatic ecosystems. Annu Rev Ecol Syst 29: 503-541

del Giorgio PA, Cole JJ (2000) Bacterial energetics and growth efficiency. In: Kirchman DL (ed) Microbial ecology of the oceans. Wiley series in ecological and applied microbiology. Wiley-Liss, New York, NY, p 289-325

Falkowski PG, Fenchel T, Delong EF (2008) The microbial engines that drive Earth's biogeochemical cycles. Science 320:1034-1039

> Franco MA, Soetaert K, Costa MJ, Vincx M, Vanaverbeke J (2008) Uptake of phytodetritus by meiobenthos using ${ }^{13} \mathrm{C}$ labelled diatoms and Phaeocystis in two contrasting sediments from the North Sea. J Exp Mar Biol Ecol 362:1-8

Gage JD, Tyler PA (1991) Deep-sea biology: a natural history of the organisms at the deep-sea floor. Cambridge University Press, Cambridge

Gillooly JF, Brown JH, West GB, Savage VM, Charnow EL (2001) Effects of size and temperature on metabolic rate. Science 293:2248-2251

Glud RN, Gundersen JK, Jorgensen BB, Revsbech NP, Schulz HD (1994) Diffusive and total oxygen uptake of deep-sea sediments in the eastern south Atlantic Ocean: in situ and laboratory measurements. Deep-Sea Res I 41:1767-1788

> Glud RN, Holby O, Hoffmann F, Canfield DE (1998) Benthic mineralization and exchange in Arctic sediments (Svalbard, Norway). Mar Ecol Prog Ser 173:237-251

Gontikaki E, Mayor DJ, Narayanaswamy BE, Witte U (in press) Feeding strategies of deep-sea sub-Arctic macrofauna of the Faroe-Shetland Channel: combining natural stable isotopes and enrichment techniques. Deep-Sea Res I doi:10.1016/j.dsr.2010.11.011

> Gooday AJ (2002) Biological responses to seasonally varying fluxes of organic matter to the ocean floor: a review. J Oceanogr 58:305-332

> Gooday AJ, Rathburn AE (1999) Temporal variability in living deep-sea foraminifera: a review. Earth Sci Rev 46:187-212

Graf G (1989) Benthic-pelagic coupling in a deep-sea benthic community. Nature 341:437-439

Grasshoff K, Kremling K, Ehrhardt M (1999) Methods of seawater analysis, 3rd edn. Wiley-VCH Verlag, Weinheim

> Guenet B, Danger M, Abbadie L, Lacroix G (2010) Priming effect: bridging the gap between terrestrial and aquatic ecology. Ecology 91:2850-2861

> Hall POJ, Brunnegard J, Hulthe G (2007) Dissolved organic matter in abyssal sediments: core recovery artefacts. Limnol Oceanogr 52:19-31

Heip CHR, Vincx M, Vranken G (1985) The ecology of marine nematodes. Oceanogr Mar Biol Annu Rev 23:399-489

Heip CHR, Duineveld G, Flach E, Graf G and others (2001) The role of the benthic biota in sedimentary metabolism and sediment-water exchange processes in the Goban Spur area (NE Atlantic). Deep-Sea Res II 48:3223-3243

Hensen C, Zabel M, Schulz HN (2006) Benthic cycling of oxygen, nitrogen and phosphorus. In: Schulz HD, Zabel M 
(eds) Marine geochemistry, 2nd edn. Springer-Verlag, Berlin, p 207-234

Hulth S, Blackburn TH, Hall POJ (1994) Arctic sediments (Svalbard): consumption and microdistribution of oxygen. Mar Chem 46:293-316

Ingels J, Van den Driessche P, De Mesel I, Vanhove S, Moens T, Vanreusel A (2010) Preferred use of bacteria over phytoplankton by deep-sea nematodes in polar regions. Mar Ecol Prog Ser 406:121-133

Jickells TD, Newton PP, King P, Lampitt RS, Boutle C (1996) A comparison of sediment trap records of particle fluxes from 19 to $48^{\circ} \mathrm{N}$ in the northeast Atlantic and their relation to surface water productivity. Deep-Sea Res I 43: 971-986

Kaariainen JI (2006) Investigating and modelling the body size structure of benthic communities. PhD thesis, University of Southampton, Southampton

Kostka JE, Thamdrup B, Glud RN, Canfield DE (1999) Rates and pathways of carbon oxidation in permanently cold Arctic sediments. Mar Ecol Prog Ser 180:7-21

Kuipers BR, de Wilde PAWJ, Creutzberg F (1981) Energy flow in a tidal flat ecosystem. Mar Ecol Prog Ser 5:215-221

> Kuzyakov Y, Friedel JK, Stahr K (2000) Review of mechanisms and quantification of priming effects. Soil Biol Biochem 32:1485-1498

Lambshead PJD, Gooday AJ (1990) The impact of seasonally deposited phytodetritus on epifaunal and shallow infaunal benthic foraminiferal populations in the bathyal northeast Atlantic: the assemblage response. Deep-Sea Res 37: 1263-1283

Lampitt RS (1985) Evidence for the seasonal deposition of detritus to the deep-sea floor and its subsequent resuspension. Deep-Sea Res 32:885-897

Lochte K (1992) Bacterial standing stock and consumption of organic carbon in the benthic boundary layer of the abyssal North Atlantic. In: Rowe GT, Pariente V (eds) Deep-sea food chains and the global carbon cycle. Kluwer Academic Publishers, Dordrecht

> Lohse L, Helder W, Epping EHG, Balzer W (1998) Recycling of organic matter along a shelf-slope transect across the NW European continental margin (Goban Spur). Prog Oceanogr 42:77-110

Mahaut ML, Sibuet M, Shiriyama Y (1995) Weight-dependent respiration rates in deep-sea organisms. Deep-Sea Res I 42:1575-1582

Middelboe M, Sondergaard M (1993) Bacterioplankton growth yield: seasonal variations and coupling to substrate lability and $\beta$-glucosidase activity. Appl Environ Microbiol 59:3916-3921

Middelboe M, Sondergaard M (1995) Concentration and bacterial utilization of sub-micron particles and dissolved organic carbon in lakes and a coastal area. Arch Hydrobiol 133:129-147

Middelboe M, Jorgensen NOG, Kroer N (1996) Effects of viruses on nutrient turnover and growth efficiency of noninfected marine bacterioplankton. Appl Environ Microbiol 62:1991-1997

Middelburg JJ, Barranguet C, Boschker HTS, Herman PMJ, Moens T, Heip CHR (2000) The fate of intertidal microphytobenthos carbon: an in situ ${ }^{13} \mathrm{C}$-labelling study. Limnol Oceanogr 45:1224-1234

> Midwood A, Gebbing T, Wendler R, Sommerkorn M, Hunt JE, Millard P (2006) Collection and storage of $\mathrm{CO}_{2}$ for ${ }^{13} \mathrm{C}$ analysis: an application to separate soil $\mathrm{CO}_{2}$ efflux into rootand soil-derived components. Rapid Comm Mass Spec 20: 3379-3384

Moens T, Verbeeck L, Vincx M (1999) Preservation and incu- bation time-induced bias in tracer-aided grazing studies on meiofauna. Mar Biol 133:69-77

Moens T, Vanhove S, De Mesel I, Kelemen B, Janssens T, Dewicke A, Vanreusel A (2007) Carbon sources of Antarctic nematodes as revealed by natural carbon isotope ratios and a pulse-chase experiment. Polar Biol 31:1-13

> Moodley L, Boschker HTS, Middelburg JJ, Pel R, Herman PMJ, de Deckere E, Heip CHR (2000) Ecological significance of benthic foraminifera: ${ }^{13} \mathrm{C}$ labelling experiments. Mar Ecol Prog Ser 202:289-295

> Moodley L, Middelburg JJ, Boschker HTS, Duineveld GCA, Pel R, Herman PMJ, Heip CHR (2002) Bacteria and foraminifera: key players in a short-term deep-sea benthic response to phytodetitus. Mar Ecol Prog Ser 236:23-29

Moodley L, Middelburg JJ, Soetaert K, Boschker HTS, Herman PMJ, Heip CHR (2005) Similar rapid response to phytodetritus deposition in shallow and deep-sea sediments. J Mar Res 63:457-469

Ohga T, Kitazato H (1997) Seasonal changes in bathyal foraminiferal populations in response to the flux of organic matter (Sagami Bay, Japan). Terra Nova 9:33-37

> Paterson E, Gebbing T, Abel C, Sim A, Telfer G (2006) Rhizodeposition shapes rhizosphere microbial community structure in organic soil. New Phytol 173:600-610

> Pfannkuche O (1993) Benthic response to the sedimentation of particulate organic matter at the BIOTRANS station, $47^{\circ} \mathrm{N}, 20^{\circ} \mathrm{W}$. Deep-Sea Res II 40:135-149

$>$ Pfannkuche O, Boetius A, Lochte K, Lundgreen U, Thiel H (1999) Responses of deep-sea benthos to sedimentation patterns in the north-east Atlantic in 1992. Deep-Sea Res I 46:573-596

> Pomeroy LR, Wiebe WJ (2001) Temperature and substrates as interactive limiting factors for marine heterotrophic bacteria. Aquat Microb Ecol 23:187-204

Ruhl HA, Smith KL Jr. (2004) Shifts in deep-sea community structure linked to climate and food supply. Science 305: 513-515

> Ruhl HA, Ellena JA, Smith KL Jr. (2008) Connections between climate, food limitation and carbon cycling in abyssal sediment communities. Proc Natl Acad Sci USA 105: 17006-17011

Sellanes J, Quiroga E, Neira C, Gutierrez D (2007) Changes of macrobenthos composition under different ENSO cycle conditions on the continental shelf off central Chile. Cont Shelf Res 27:1002-1016

Smith KL (1987) Food energy supply and demand: a discrepancy between particulate organic carbon flux and sediment community oxygen consumption in the deep ocean. Limnol Oceanogr 32:201-220

Smith KL, Kaufmann RS, Baldwin RJ (1994) Coupling nearbottom pelagic and benthic processes at abyssal depths in the eastern north Pacific Ocean. Limnol Oceanogr 39: 1101-1118

Soetaert K, Vanaverbeke J, Heip CHR, Herman PMJ, Middelburg JJ, Sandee A, Duineveld G (1997) Nematode distribution in ocean margin sediments of the Goban Spur (northeast Atlantic) in relation to sediment geochemistry. Deep-Sea Res I 44:1671-1683

Sweetman AK, Witte U (2008) Macrofaunal response to phytodetritus in a bathyal Norwegian fjord. Deep-Sea Res I 55:1503-1514

Tamburini C, Garcin J, Bianchi A (2003) Role of deep-sea bacteria in organic matter mineralization and adaptation to hydrostatic pressure conditions in the NW Mediterranean Sea. Aquat Microb Ecol 32:209-218

> Turley CM, Lochte K, Lampitt RS (1995) Transformations of biogenic particles during sedimentation in the northeast 
Atlantic. Phil Trans R Soc London Ser B 348:179-189

Turrell WR, Slesser G, Adams RD, Payne R, Gillibrand PA (1999) Decadal variability in the composition of Faroe Shetland Channel bottom water. Deep-Sea Res I 46:1-25

Urban-Malinga B, Moens T (2006) Fate of organic matter in Arctic intertidal sediments: Is utilization by meiofauna important? J Sea Res 56:239-248

van Nugteren P, Moodley L, Brummer GJ, Heip CHR, Herman PMJ, Middelburg JJ (2009) Seafloor ecosystem functioning: the importance of organic matter priming. Mar Biol 156:2277-2287

Wassmann P (1998) Retention versus export food chains: processes controlling sinking loss from marine pelagic systems. Hydrobiologia 363:29-57

White DC, Davis WM, Nickels JS, King JD, Bobbie RJ (1979) Determination of the sedimentary microbial biomass by

Editorial responsibility: Ronald Kiene,

Mobile, Alabama, USA extractible lipid phosphate. Oecologia 40:51-62

- Witte U, Aberle N, Sand M, Wenzhofer F (2003a) Rapid response of a deep-sea benthic community to POM enrichment: an in situ experimental study. Mar Ecol Prog Ser 251: $27-36$

Witte U, Wenzhofer F, Sommer S, Boetius A and others (2003b) In situ experimental evidence of the fate of a phytodetritus pulse at the abyssal sea floor. Nature 424: 763-766

Woulds C, Cowie GL, Levin LA, Andersson JH and others (2007) Oxygen as a control on seafloor biological communities and their roles in sedimentary carbon cycling. Limnol Oceanogr 52:1698-1709

Woulds C, Andersson JH, Cowie GL, Middelburg JJ, Levin LA (2009) The short-term fate of organic carbon in marine sediments: comparing the Pakistan margin to other regions. Deep-Sea Res I 56:393-402

Submitted: March 30, 2010; Accepted: October 20, 2010

Proofs received from author(s): December 10, 2010 